Recensies

\title{
MARC SLORS OVER DE VRIJE WL
}

Marc Slors, Dat had je gedacht! Brein, bewrustzijn en vrije wil in filosofisch perspectief, Amsterdam, Boom, 2012, 201 pp., € 18,90 ISBN 9789461057785

'Het wel lijkt alsof filosofen elkaar naar het leven staan als het gaat over de vrije wil', merkte een vriend onlangs verwonderd op. Het moet inderdaad gezegd, het vrije-wil-scepticisme van vandaag stuit op heel wat weerstand en verontwaardiging, en het vrije wilsdebat - dat zich ondertussen via de populaire media moeiteloos een weg heeft gebaand naar het bredere publiek - verloopt niet zelden hard tegen onzacht. Die intensiteit is belangwekkend op zich; misschien zelfs dermate dat men het waarom en waartoe van al die heisa vanuit filosofisch oogpunt op de lange duur interessanter zou gaan vinden dan de vraag of die vrije wil nu wel of niet bestaat.Er staat blijkbaar heel wat op het spel, en vanuit dat perspectief komt de grondvraag van Marc Slors' nieuwste boek - waar gaat het eigenlijk over? (p. 9) - niets te vroeg.

In Dat had je gedacht! Brein, bewustzijn en vrije wil in filosofisch perspectief belooft Slors - hoogleraar cognitiefilosofie aan de Radboud Universiteit (Nijmegen) - in de eerste plaats klaarheid te scheppen in 'de loopgravenoorlog' (p. 9) die het vrije wilsdebat is geworden. Bovendien moet dat helder, duidelijk, en wars van elk 'protectionisme' (p. 15). Als het aankomt op duidelijkheid en scherpte is Slors' meest recente pennenvrucht inderdaad een hoogvlieger; het boek leest erg vlot, is helder gestructureerd, en omwille van de talrijke voorbeelden heel toegankelijk. Anderzijds houdt diezelfde doorgedreven exemplarische aanpak - Slors neemt ons mee in de keuken, naar de supermarkt, en naar het voetbal - onvermijdelijk een hachelijke evenwichtsoefening in tussen verhelderende vereenvoudiging en oversimplificatie. Al blijkt de auteur die oefening op het eind van de rit wonderwel te hebben doorstaan, het blijft toch wat (oncomfortabel?) balanceren, zoals dat wel vaker het geval is met populariserende werken. Hoe het ook zij: het is van in het begin duidelijk dat Slors het vrije wilsdebat allerminst beschouwt als een wandeling door het park. Dat had je gedacht! gaat achtereenvolgens in op (i) de neurowetenschappelijke basis en de inzet van de discussie (hoofdstuk 1-3), om vervolgens (ii) in hoofdstukken 4 en 5 de rationale waarop het vrije-wil-scepticisme is gebaseerd te analyseren en bekritiseren, om dan tot slot (iii) een aanzet te formuleren tot een meer geïntegreerde benadering van menselijke agentiviteit in de laatste drie hoofdstukken.

Slors slaagt erin vragen op een heldere manier van elkaar te onderscheiden 
(bewustzijn, zelf, en vrije wil) en zo een aantal prikkelende kritische suggesties te doen met betrekking tot de inzet, de reikwijdte en de grenzen van het vrije wilsdebat. Het is inderdaad zo dat het neurowetenschappelijke onderzoek van voornamelijk Benjamin Libet en Daniel Wegner overtuigend aantoonde dat bewuste intenties pas ontstaan nadat het brein een handeling reeds aan het voorbereiden is, en bovendien dat de bewuste ervaring van het 'zelf' als oorzaak van het handelen feilbaar - of sterker nog: illusoir - is. Het bewuste 'ik' hinkt daarmee niet alleen achterop op het brein (Libet), het interpreteert, verdraait, of confabuleert volgens sommigen zelfs het causale verband tussen handelingen en gebeurtenissen. Marc Slors laat geen twijfel bestaan over het feit dat deze onderzoeken iets belangrijks aan het licht brengen over het menselijke handelen en zo een impact hebben (of moeten hebben) op de manier waarop de vrije wil in de filosofie wordt bevraagd. De vraag is alleen: wat zeggen ze precies?

Vanaf het vierde hoofdstuk argumenteert Slors overtuigend dat dat alvast niets is over de vrije wil, maar wel over de plaats en functie van het bewustzijn in menselijk gedrag. Voor de Nederlandse filosoof knelt het schoentje in de hele kwestie bij de identificatie van het zelf kiezen en het bewust kiezen, en meer bepaald bij het feit dat de "stap van bewuste wil naar vrije wil [...] moeiteloos wordt gezet - zonder enige vorm van argumentatie" (pp. 79-80). Maar is bijvoorbeeld het spreken niet bij uitstek iets dat én grotendeels onbewust verloopt, én intentioneel is, én van mezelf is, oppert de auteur terecht (p. 97). En is de tijd niet gekomen om dat Cartesiaanse cogito, waarin zelf en bewustzijn samenvallen, naast ons neer te leggen, vraagt hij zich nog af? Hoofdstuk vier geeft daarmee ook een aanzet tot historische inbedding van de manier waarop filosofische vraagstukken over het zelf, het bewustzijn, en vrijheid, zijn verknoopt, al is deze historische dimensie wat afwezig in de rest van het boek.

Naast de negatieve these dat de neurowetenschappen niets zeggen over de vrije wil, maar wel over de rol van het bewustzijn in het menselijke handelen, lezen we in Slors' boek ook een voorzichtige positieve suggestie, een aansporing om het begrip vrije wil (en haar problemen) wat eleganter te gaan denken, op een manier die recht doet aan de complexiteit van de menselijke agentiviteit. In hoofdstuk 6 en 7 krijgen we een aanzet tot zo'n 'ander' verhaal. Ten eerste (hoofdstuk 6), stelt Slors, mag het dan nog zo zijn dat bewuste intenties geen (of slechts een minieme) rol spelen als directe, initiërende oorzaak van ons handelen, op lange termijn kunnen ze wel het gedrag 'structureren' of 'programmeren' (p. 132), door in te werken op onbewuste neigingen en voorkeuren. Het bewustzijn wordt hierbij voor Slors - geinspireerd door de Amerikaanse psycholoog Roy Baumeister - een "Tomtom die het onbewuste de weg wijst" (p. 134). Ten tweede neemt de auteur ook Wegners interpretatie van het bewustzijn als 'kwebbeldoos' op de korrel. Het bewuste 'ik' confabuleert niet (altijd) zonder meer de redenen voor gedrag in een achterafbeweging, het interpreteert op een zinvolle manier zo luidt het, dit is op een manier "die strookt 
met een heleboel feiten die ik over mezelf weet" (p. 151). Ook het 'zelf' krijgt daarmee een andere invulling, namelijk niet als controlerende entiteit, maar als identiteit. In het laatste hoofdstuk schematiseert de auteur nog de resultaten van zijn kritische analyse in een meer integratief model van het menselijke handelen, dat uitgaat van de interactie tussen bewuste en onbewuste processen, en waarin het bewustzijn primair de functie krijgt van interpreterende en structurerende entiteit.

Aan het eind van de rit blijkt Dat had je gedacht! een onderhoudende introductie op het vrije wilsdebat, onder meer omwille van de pertinente analyse van de (impliciete) rationale waarin het vrije-wil-scepticisme is gefundeerd. Naast het beloofde "waar gaat het eigenlijk over?" reflecteert Slors over het "waar gaat het alvast niet over?" en het "waar zou het moeten over gaan?", vragen die jammer genoeg soms wat verloren lijken te gaan in de exclusieve bekommernis om dat eeuwige 'bestaat die vrije wil nu of niet'? Al laat het werk enkele belangrijke vraagstukken links liggen - bijvoorbeeld de ideologische inzet van het debat, en haar mogelijke praktische consequenties op bijvoorbeeld het juridische of psychologische domein - het is een aanrader voor al wie op zoek is naar wat meer inzicht in de discussie, en een mogelijk alternatief perspectief. 